
\title{
$\begin{array}{ll}\text { Research Square } & \begin{array}{l}\text { Preprints are preliminary reports that have not undergone peer review. } \\ \text { They should not be considered conclusive, used to inform clinical practice, } \\ \text { or referenced by the media as validated information. }\end{array}\end{array}$
}

\section{Experience of Emergency Medical Services Response to Arasbaran Earthquakes in 2012: A Qualitative Study}

Mahboub Poueaghaei

Tabriz University of Medical Sciences

Javad Babaie ( $\sim$ javad1403@yahoo.com )

Tabriz University of Medical Sciences https://orcid.org/0000-0001-6155-5606

Laleh Rad Saeed

Tabriz University of Medical Sciences

\section{Research article}

Keywords: Emergency Medical Services, Injury, Hospital, Earthquake, Response, Disaster, Emergency

Posted Date: May 4th, 2020

DOl: https://doi.org/10.21203/rs.3.rs-24499/v1

License: () (i) This work is licensed under a Creative Commons Attribution 4.0 International License. Read Full License 


\section{Abstract}

Background One of the most important concerns in responding to disasters is providing Basic Life Support (BLS) services to injuries. Considering the key role of Emergency Medical Services (EMS) in providing BLS, the purpose of this study is to investigate the experience of provincial EMS's response to the Arasbaran twin earthquakes and its challenges in 2012 in Iran.

Methods In this qualitative content analysis, data were collected through Focus Group Discussions (FGD) and semi-structured in-depth interviews with purposefully-selected EMS paramedics and officers in East Azerbaijan Province, Iran. To form the main categories, the interviews were encoded in three stages and the similar codes were placed under the same subcategories and merged.

Results A total of 26 EMS paramedics and officers participated in the study. The codes extracted from their interviews were divided into ten categories, including; the lack of preparedness and coordination, dead bodies' management challenges, responders' psychosocial support, deficiencies in supplies and ambulances, difficulty of access to rural areas, volunteer management, non-documentation of the experiences, communication challenges, recalling and deploying of EMS responders.

Conclusion According to the findings, EMS timely response and paramedic's sense of responsibility for providing services were a positive point about the EMS operations. The weaknesses of the system should therefore be addressed through transferring of experiences and by planning and arranging training courses.

\section{Background}

Disasters are imposed on human life as destructive phenomena ${ }^{[1,2 \text { and } 3]}$. In 2017, for example, 318 disasters occurred throughout the world, with 9503 deaths, more than 96 million affected and more than $\$ 314$ billion in financial damages ${ }^{[4]}$.

Iran is one of the most disaster-prone countries in the world. Most of hazards that have been identified on earth have the potential to occur in Iran. More than $90 \%$ of the country and almost all its mega cities are at risk of floods and earthquakes ${ }^{[5,6]}$.

Disasters, particularly those who release a lot of energy, damage the structures and injure people. Rescuing these casualties from the rubble and providing immediate medical care can reduce many deaths and complications ${ }^{[7]}$. Medical services are the most important demand of the affected people during the first moments after disasters. Therefore, pre-hospital EMS is one of the key components of every disaster response [7], and since the launch of these systems in the world, they have become the leading organization in response to disasters ${ }^{[8]}$.

EMS is the main providers of BLSs in the early moments after a disaster ${ }^{[8]}$. There is a lot of evidence showing the preparedness of these systems, and their timely and effective response has significantly reduced the deaths and adverse effects of disasters ${ }^{[9]}$.

On August 21, 2012, two earthquakes, with a magnitude of 6.2 and 6.3 on the Richter scale, shook the Haris, Varzaghan and Ahar (Arasbaran) districts in East Azerbaijan Province and injured more than 3000 [10]. The provincial pre-hospital emergency department was involved in response to the earthquakes. Many disaster management specialists believe that these experiences should be constantly investigated and their strengths and weaknesses extracted. Thus the aim of this study is to extract the experiences of East Azerbaijan EMS in response to Arasbran twine earthquakes.

\section{Methods}

Purposively selected EMS paramedics and officials who were involved in responding to Ahar, Varzaghan and Haris earthquake in 2012 were the participants of this content analysis qualitative study. After receiving the consent of Tabriz University of Medical Sciences, the researchers were referred to the central EMS organization in Tabriz. The selected participants consonant were obtained written and then they interviewed or coordinated by FGD. The number of participants in each FGD was five to seven. The group discussions and interviews continued until data saturation was achieved. The inclusion criteria for this study consisted of having being involved in these response operations as an EMS paramedic or officer. The exclusion criterion was unwillingness to participate in the study. The interviews and group discussions began with the interviewer presenting a summary of the project and its objectives to the interviewees. The interviews then began with general questions, and based on participants' responses, more in-depth questions were asked to extract rich interviewee experiences. All the responses were recorded by a recorder and immediately transcribed after the completion of the interview. A summary of all the discussions and participants' behavior and body language during the sessions were recorded. All the statements made by the participants were then transcribed on paper with the exact same wording and were submitted to each participant to correct their statements. The text of the interviews and discussion was repeatedly studied to achieve immersion. Data extraction began after this stage. Data analysis was carried out in the form of content analysis, and started simultaneously in three stages (simultaneous analysis). At first, the initial codes were determined. The duplicate codes then were removed and the codes with the same concept were placed together to form the subcategories. The main categories were formed out of the merged subcategories.

\section{Results}

Four FGDs and five interviews were held with 26 participants. Eighteen of them were EMS paramedics and eight were officials. Seven of the participants were women and 19 were men. All of them had either participated directly in providing services to the injured people in the early hours after the earthquakes or had been involved in managing the response. Table 1 presents their profile. 
Table 1

The demographic characteristics of the study participants

\begin{tabular}{|c|c|c|c|}
\hline & Title & Number & Percentage \\
\hline \multirow[t]{5}{*}{ Education } & General physician & 5 & 19.23 \\
\hline & Master & 4 & 15.38 \\
\hline & Bachelor & 11 & 42.31 \\
\hline & Associate Degree & 6 & 23.08 \\
\hline & Total & 26 & 100 \\
\hline \multirow[t]{7}{*}{ Work Experience } & More than 25 years & 4 & 15.38 \\
\hline & $20-24$ years & 6 & 23.08 \\
\hline & $15-19$ years & 5 & 19.23 \\
\hline & $10-14$ years & 4 & 15.38 \\
\hline & $5-9$ years & 3 & 11.54 \\
\hline & Less than 5 years & 4 & 15.38 \\
\hline & Total & 26 & 100 \\
\hline \multirow[t]{4}{*}{ Workplace } & Emergency Department & 11 & 42.31 \\
\hline & City EMS headquarters & 5 & 19.23 \\
\hline & EMS headquarters of the province & 10 & 38.48 \\
\hline & Total & 26 & 100 \\
\hline
\end{tabular}

After the earthquakes, EMS started its response operation at two levels, including the district (local) and the provincial level. The paramedics who were present at the local EMS posts in the earthquake-affected area had gone to the nearest villages from the very first moments after the turmoil along with other people and began to gather the injured in certain points, prioritize them and provide basic medical services to them; then, using ambulances, they began transferring the injured to Ahar, Haris and Varzaghan hospitals. At the local level, since the earthquake occurred in the afternoon and the buildings were closed and since the cities themselves were not badly damaged, the paramedics first ensured the family's health and then deployed them locally (mostly to relatives' homes) and immediately went to their departments and started the response operation.

In the provincial department, almost all the officers had set up their families in a safe place after learning of the earthquake and had come back to their workplace within the first minutes. They had then begun getting information from places hit by the earthquakes. After getting the initial information, three rapid assessment teams were deployed to the affected areas. Afterwards, the officers began calling on other coworkers from the provincial towns, and after about two hours, ambulances deployed to the affected zones. As the earthquake-affected cities were in the neighboring province of Ardabil, ambulances were immediately sent from this province to the city of Ahar for relief. More ambulances were sent from West Azerbaijan Province. Despite these efforts, most of the injured had reached the hospitals by their own personal cars, which were mostly unsuitable for carrying an injured. Overall, more than 3000 earthquake victims were transferred to hospitals in the region. The initial response was almost completed around 2:00 AM (approximately eight hours after the first shakes).

After the analysis of the FGDs and interviews and their encoding, the codes were finally extracted by eliminating the repetitive codes and merging the similar items. The similar codes were placed into subcategories, yielding 32 subcategories. The similar subcategories were also merged to form the top ten categories, including:

Lack of EMS preparedness

Lack of coordination

The challenge of dead bodies management

Lack of psychosocial support for the EMS responders

Deficiencies and the lack of facilities, equipment, supplies and ambulances

Difficulty of access to damaged rural areas

Relief volunteer management

Lack of documentation of experiences

The challenges of communicating with the earthquake-affected areas and between teams

Recalling and deploying EMS responders

Table 2 presents the details of the codes, subcategories and categories. 
Table 2

The categories and sub-categories extracted from the interviews and FGDs

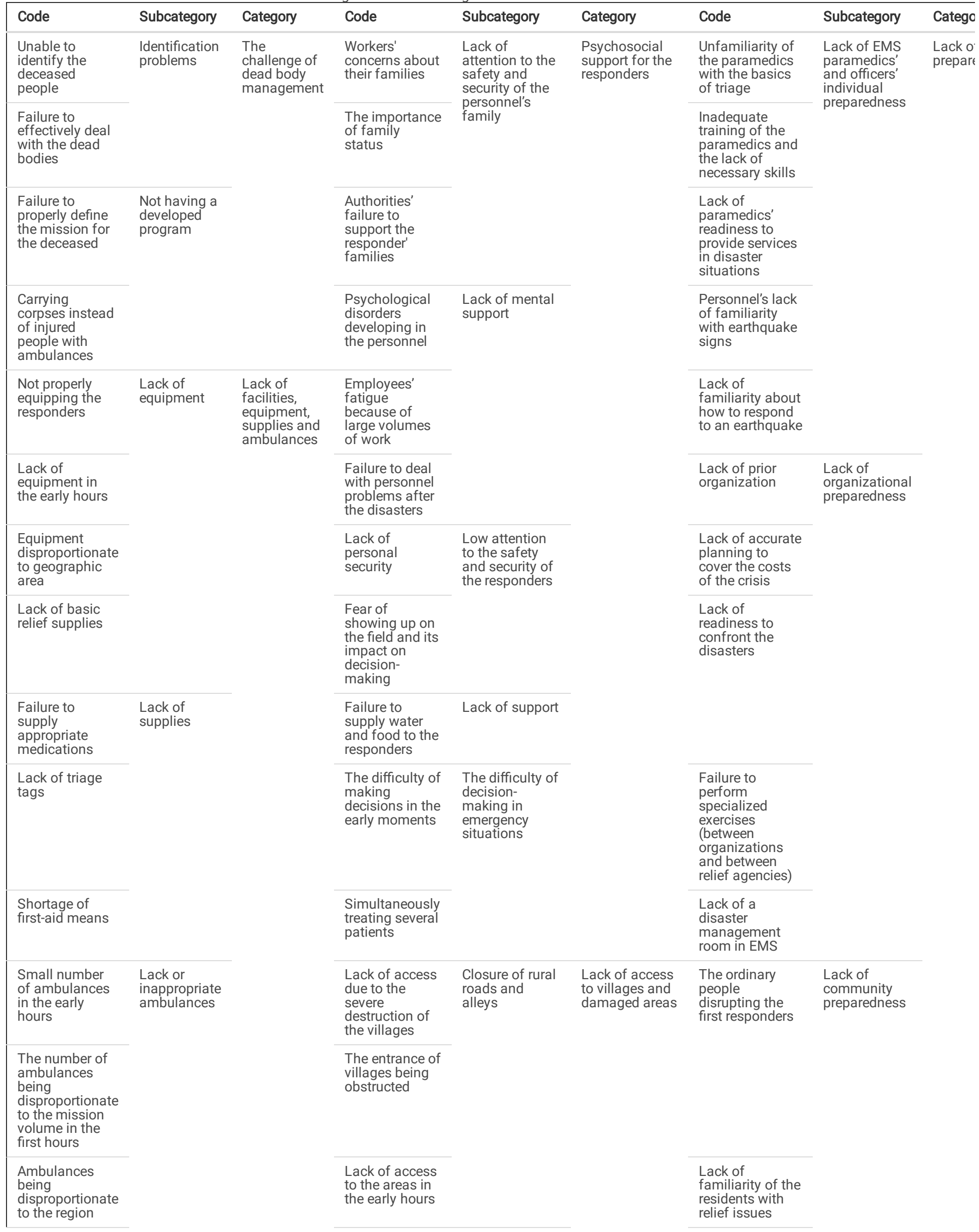




\begin{tabular}{|c|c|c|c|c|c|c|c|c|}
\hline Code & Subcategory & Category & Code & Subcategory & Category & Code & Subcategory & Categc \\
\hline $\begin{array}{l}\text { Ambulances not } \\
\text { appropriate for } \\
\text { disaster } \\
\text { situations }\end{array}$ & & & $\begin{array}{l}\text { Poorly- } \\
\text { constructed } \\
\text { regional roads }\end{array}$ & $\begin{array}{l}\text { Poorly- } \\
\text { constructed } \\
\text { rural roads }\end{array}$ & & $\begin{array}{l}\text { The local } \\
\text { people's inability } \\
\text { to perform } \\
\text { proper triage }\end{array}$ & & \\
\hline $\begin{array}{l}\text { Lack of } \\
\text { advanced } \\
\text { facilities and } \\
\text { ambulances }\end{array}$ & & & $\begin{array}{l}\text { Geographical } \\
\text { conditions }\end{array}$ & & & & & \\
\hline $\begin{array}{l}\text { The } \\
\text { impossibility of } \\
\text { landing } \\
\text { helicopters }\end{array}$ & & & $\begin{array}{l}\text { Damage to the } \\
\text { roads and } \\
\text { bridges }\end{array}$ & $\begin{array}{l}\text { Destruction of } \\
\text { communication } \\
\text { routes }\end{array}$ & & $\begin{array}{l}\text { The people's } \\
\text { inability to } \\
\text { perform medical } \\
\text { first aids }\end{array}$ & & \\
\hline $\begin{array}{l}\text { Inviting people } \\
\text { to help the } \\
\text { responders }\end{array}$ & \multirow[t]{4}{*}{$\begin{array}{l}\text { Community } \\
\text { relief }\end{array}$} & \multirow[t]{10}{*}{$\begin{array}{l}\text { Managing } \\
\text { Volunteers } \\
\text { and People's } \\
\text { Aid }\end{array}$} & Road traffic & & & $\begin{array}{l}\text { Misalignment in } \\
\text { missions by } \\
\text { ambulances }\end{array}$ & $\begin{array}{l}\text { Lack of inter- } \\
\text { sectional } \\
\text { coordination }\end{array}$ & $\begin{array}{l}\text { Lack o } \\
\text { coordir }\end{array}$ \\
\hline $\begin{array}{l}\text { People } \\
\text { transferring the } \\
\text { patients to } \\
\text { health centers }\end{array}$ & & & Road closure & & & & & \\
\hline $\begin{array}{l}\text { Community } \\
\text { members } \\
\text { rescuing and } \\
\text { prioritizing the } \\
\text { injured }\end{array}$ & & & $\begin{array}{l}\text { Failure to } \\
\text { transfer } \\
\text { experiences to } \\
\text { other relief } \\
\text { forces }\end{array}$ & $\begin{array}{l}\text { No lessons } \\
\text { learnt from the } \\
\text { past }\end{array}$ & $\begin{array}{l}\text { No lessons } \\
\text { learnt from the } \\
\text { past }\end{array}$ & $\begin{array}{l}\text { Inconsistencies } \\
\text { between pre- } \\
\text { hospital and } \\
\text { hospital } \\
\text { emergencies }\end{array}$ & & \\
\hline $\begin{array}{l}\text { People } \\
\text { dominating the } \\
\text { management of } \\
\text { the scene }\end{array}$ & & & $\begin{array}{l}\text { No lessons } \\
\text { learnt from the } \\
\text { past }\end{array}$ & & & $\begin{array}{l}\text { Uncoordinated } \\
\text { forces' decisions }\end{array}$ & & \\
\hline $\begin{array}{l}\text { The abundance } \\
\text { of popular and } \\
\text { organizational } \\
\text { gifts }\end{array}$ & \multirow[t]{2}{*}{$\begin{array}{l}\text { Community } \\
\text { donations }\end{array}$} & & $\begin{array}{l}\text { Suspension of } \\
\text { measures after } \\
\text { the change of } \\
\text { management }\end{array}$ & & & $\begin{array}{l}\text { Uncoordinated } \\
\text { management of } \\
\text { ambulances }\end{array}$ & & \\
\hline $\begin{array}{l}\text { The existence of } \\
\text { spontaneous } \\
\text { help from the } \\
\text { people }\end{array}$ & & & $\begin{array}{l}\text { Failure to } \\
\text { improve post- } \\
\text { earthquake } \\
\text { affairs }\end{array}$ & $\begin{array}{l}\text { Not learning } \\
\text { from this } \\
\text { earthquake }\end{array}$ & & $\begin{array}{l}\text { Lack of full } \\
\text { access to all the } \\
\text { facilities } \\
\text { available at the } \\
\text { local level }\end{array}$ & & \\
\hline $\begin{array}{l}\text { People's } \\
\text { insistence on } \\
\text { receiving } \\
\text { services } \\
\text { themselves }\end{array}$ & \multirow[t]{4}{*}{$\begin{array}{l}\text { Challenges } \\
\text { of people's } \\
\text { presence on } \\
\text { the scene }\end{array}$} & & $\begin{array}{l}\text { Failure to act } \\
\text { on the } \\
\text { experiences of } \\
\text { the Ahar-Haris } \\
\text { incident }\end{array}$ & & & $\begin{array}{l}\text { Non-therapeutic } \\
\text { intervention in } \\
\text { treatment }\end{array}$ & \multirow[t]{4}{*}{$\begin{array}{l}\text { Lack of intra- } \\
\text { sectional } \\
\text { coordination }\end{array}$} & \\
\hline $\begin{array}{l}\text { The influx of } \\
\text { people and } \\
\text { residents into } \\
\text { health and } \\
\text { service centers }\end{array}$ & & & $\begin{array}{l}\text { Not taking } \\
\text { advantage of } \\
\text { past } \\
\text { experiences }\end{array}$ & \multirow[t]{3}{*}{$\begin{array}{l}\text { Lack of } \\
\text { document } \\
\text { actions }\end{array}$} & & $\begin{array}{l}\text { Unfamiliarity of } \\
\text { the } \\
\text { organizations } \\
\text { involved in } \\
\text { responding with } \\
\text { each other's } \\
\text { tasks }\end{array}$ & & \\
\hline $\begin{array}{l}\text { Involvement of } \\
\text { ordinary people } \\
\text { in therapeutic } \\
\text { measures and } \\
\text { triage }\end{array}$ & & & $\begin{array}{l}\text { Failure to } \\
\text { record the } \\
\text { response } \\
\text { experience }\end{array}$ & & & $\begin{array}{l}\text { Lack of } \\
\text { coordination } \\
\text { between the } \\
\text { organizations }\end{array}$ & & \\
\hline $\begin{array}{l}\text { The gathering } \\
\text { of people and } \\
\text { residents in } \\
\text { health centers }\end{array}$ & & & & & & $\begin{array}{l}\text { Lack of } \\
\text { coordination in } \\
\text { supplying } \\
\text { staffing needs }\end{array}$ & & \\
\hline $\begin{array}{l}\text { Calling on all } \\
\text { the ready forces }\end{array}$ & & \multirow[t]{3}{*}{$\begin{array}{l}\text { Recall and } \\
\text { management } \\
\text { of volunteers }\end{array}$} & $\begin{array}{l}\text { Disconnection } \\
\text { from all } \\
\text { sources of } \\
\text { communication } \\
\text { in the early } \\
\text { hours }\end{array}$ & \multirow[t]{3}{*}{$\begin{array}{l}\text { Communication } \\
\text { interruptions }\end{array}$} & \multirow{3}{*}{$\begin{array}{l}\text { The challenge } \\
\text { of } \\
\text { communicating } \\
\text { with } \\
\text { earthquake- } \\
\text { affected areas } \\
\text { and between } \\
\text { teams }\end{array}$} & $\begin{array}{l}\text { Relief turmoil in } \\
\text { the affected } \\
\text { villages }\end{array}$ & \multirow[t]{3}{*}{$\begin{array}{l}\text { Lack of unity } \\
\text { of commands }\end{array}$} & \\
\hline $\begin{array}{l}\text { Quickly sending } \\
\text { donations from } \\
\text { other provinces }\end{array}$ & & & $\begin{array}{l}\text { Satellite } \\
\text { phones not } \\
\text { operating }\end{array}$ & & & $\begin{array}{l}\text { Lack of access } \\
\text { to the authorities }\end{array}$ & & \\
\hline $\begin{array}{l}\text { Deployment of } \\
\text { forces from } \\
\text { different routes }\end{array}$ & $\begin{array}{l}\text { Calling on } \\
\text { and dispatch } \\
\text { of forces }\end{array}$ & & & & & $\begin{array}{l}\text { Unaccountability } \\
\text { of the officials }\end{array}$ & & \\
\hline
\end{tabular}




\begin{tabular}{|c|c|c|c|c|c|c|c|c|}
\hline Code & Subcategory & Category & Code & Subcategory & Category & Code & Subcategory & Categc \\
\hline $\begin{array}{l}\text { Rapid } \\
\text { deployment of } \\
\text { responders from } \\
\text { Tabriz center }\end{array}$ & & & $\begin{array}{l}\text { Difficulty of } \\
\text { communication } \\
\text { with the rescue } \\
\text { teams }\end{array}$ & \multirow[t]{5}{*}{$\begin{array}{l}\text { Lack of } \\
\text { communication } \\
\text { equipment }\end{array}$} & & $\begin{array}{l}\text { Not offering a } \\
\text { definition of } \\
\text { responsibility to } \\
\text { the forces }\end{array}$ & & \\
\hline $\begin{array}{l}\text { Cooperation } \\
\text { and readiness } \\
\text { of other } \\
\text { provinces }\end{array}$ & & & $\begin{array}{l}\text { Lack of } \\
\text { communication } \\
\text { equipment }\end{array}$ & & & $\begin{array}{l}\text { Lack of time } \\
\text { management for } \\
\text { helping in the } \\
\text { early hours }\end{array}$ & & \\
\hline $\begin{array}{l}\text { The arrival of } \\
\text { auxiliary forces } \\
\text { from } \\
\text { neighboring } \\
\text { cities }\end{array}$ & & & $\begin{array}{l}\text { Lack of private } \\
\text { communication } \\
\text { systems }\end{array}$ & & & $\begin{array}{l}\text { Poor allocation } \\
\text { of paramedics } \\
\text { to the areas }\end{array}$ & & \\
\hline $\begin{array}{l}\text { High sense of } \\
\text { responsibility } \\
\text { among the } \\
\text { personnel }\end{array}$ & \multirow[t]{3}{*}{$\begin{array}{l}\text { High } \\
\text { motivation to } \\
\text { provide } \\
\text { services }\end{array}$} & & $\begin{array}{l}\text { Lack of } \\
\text { communication } \\
\text { equipment in } \\
\text { ambulances }\end{array}$ & & & $\begin{array}{l}\text { Collecting } \\
\text { earthquake } \\
\text { information by } \\
\text { visiting the site }\end{array}$ & \multirow[t]{3}{*}{$\begin{array}{l}\text { Failure to } \\
\text { perform a } \\
\text { quick } \\
\text { assessment in } \\
\text { the first hours }\end{array}$} & \\
\hline $\begin{array}{l}\text { Rapid arrival of } \\
\text { equipment and } \\
\text { assistance from } \\
\text { Tehran }\end{array}$ & & & $\begin{array}{l}\text { Lack of } \\
\text { physical } \\
\text { facilities for } \\
\text { communication }\end{array}$ & & & $\begin{array}{l}\text { Dispersed } \\
\text { information in } \\
\text { the first minutes } \\
\text { of the incident }\end{array}$ & & \\
\hline $\begin{array}{l}\text { Fast delivery of } \\
\text { equipment }\end{array}$ & & & $\begin{array}{l}\text { Lack of access } \\
\text { to SMS }\end{array}$ & $\begin{array}{l}\text { Results from } \\
\text { communication } \\
\text { problems }\end{array}$ & & $\begin{array}{l}\text { Failure to } \\
\text { perform an early } \\
\text { initial needs } \\
\text { assessment }\end{array}$ & & \\
\hline
\end{tabular}

\section{1- Lack Of Ems Preparedness}

The lack of preparedness in the EMS paramedics and officers was one of the main issues discussed by most interviewees. The lack of preparedness was reported at different levels and has been divided into three sub-categories: The lack of paramedics' and officer's preparedness, the lack of EMS organizations' preparedness and the lack of community preparedness. Examples of participants' statements are given below:

... We did not know that there was an earthquake; we were afraid, but did not know what to do ..." "... We have been trained to provide services in the case of road accidents and emergency situations such as heart attacks. We did not know what to do there ..." “... We never had a maneuver that covered such a situation ..." "... People didn't know what triage was. They didn't know how to help us. They put a lot of pressure on us ...

\section{2- The Lack Of Coordination}

The most frequently discussed issue by the interviewees was the lack of coordination, which entailed internal (EMS) and external (between the different relief organizations) levels. The lack of internal coordination refers to coordination in missions, dispatches and organizing of responders and equipment, and the lack of external or intersectional coordination mainly means the inconsistency of different organizations with each other in providing services.

There were numerous challenges in managing and organizing relief affairs in the affected areas. Rapid assessment was not carried out in the early hours of the incident, and more pressure was put on EMS organizations that revealed their managers' weakness in the allocation of equipment and human resources.

... We became involved with the police and the police hit our colleagues. They insisted that we should take the corps with us ..." "... We didn't know where to go; the division was poor, and everyone gave a command. He said you were going to the village of Varzaghan, or you go to the villages around Tabriz, and so on" "... Another problem was protection..." "...The university had good facilities; we couldn't serve them all though ..." "The security forces contacted our colleagues; unfortunately, they think we are under their control and should listen to whatever they say ..." "... The school watchman resisted opening the school ..." "... In that village, there were a few injuries, but the number of ambulances was higher ...

\section{3-The Challenge Of Dead Bodies Management}

Another challenge noted by the interviewees was the challenge of managing the dead bodies; that is, the inability to identify, organize and transport the deceased bodies.

"... Some of the corpses were not recognizable ..." "I saw an ambulance bring a corpse ..." "... We didn't know what to do with the bodies, and people also pressured us ..." "... Where should we put them? ...".

\section{4- Psychosocial Support For The Ems Responders}

From the viewpoint of the interviewees, the lack of mental support for the EMS personnel, the lack of attention to the safety and security of them and their families, the lack of proper water and food supply and the presence of fear and unrest in emergency situations affect correct decision-making and deployment 
of responders and put the personnel in unfavorable conditions.

... I gave everything to my nephew and carried my car to Varzaghan ..." "... I was able to call my family, who said they were good and safe ..." "... We were worried about our own families ..." "They said all the troops have gone to their own families' rescue ..." "... Everyone received tents and the basic necessities except our own families ..." "... After the earthquake, nobody came to us to see how we were finally doing ..." "... We are always neglected by the staff...

\section{5- Deficiencies and the lack of facilities, equipment, supplies and ambulances}

The most common problems noted by the participants included the lack of equipment, especially in the early hours after the incident, the lack of supplies and treatment facilities, the failure to supply appropriate medications to the injured and inappropriate or lack of ambulances and the lack of proper and balanced allocation of equipment to the earthquake-affected areas.

"... There was an ambulance and we brought eight patients on it ..." "... Our ambulances are Sprinter and not suitable for our area ..." "... The equipment is very important. We have many shortcomings..." "... We are not equipped with clothes..." "... We didn't have tags for the triage".

6- The Challenge Of Access To Villages And Damaged Areas

Access to villages was very difficult, and the rural texture of the earthquake-affected areas (narrow streets and rural roads) also exacerbated this problem. Some road bridges were either destroyed or completely unreliable. Some roads could not be crossed due to the collapse of the mountains or because they were subsiding. In the first moments, heavy traffic was created on the roads that delayed the response.

... We went there and I saw that both the entrance and the exit were destroyed. We had to keep on the bridge ..." "... There was about 30 centimeters subsidence in the direction of the road ..." "... Our second problem was the traffic; after the announcement of the earthquake in these three areas, the road was actually blocked ..." "... On the Khaje-Haris path, the mountain had collapsed ...

7- Relief Volunteer And Donation Management

The participants discussed the role of volunteers in the process of providing relief to the injured and public and organizational donations. They also discussed the problems and challenges of people's presence in the regions, which mainly included people's pressures to receive services, invasions of and gatherings in health centers and interferences in the provision of health care.

... Several trucks brought in patients ..." "... I think about $10 \%$ of the injured were brought in by EMS personnel and the rest by the locals. People themselves took over the situation and did everything by themselves ..." "... People insisted that we take their patients and did not let us do triage ..." "... They disturbed our efforts for triage as soon as they saw us in our uniforms ..." "People came and went to help the injured trapped beneath the rubble ...

8- The Lack Of Documentation Of Experiences

Almost all the EMS responders had not recorded their experiences, including the actions taken, the existing problems and challenges, potential solutions and the strengths and weaknesses of each decision and action. This lack of documentation impedes the transfer of experience to other responders and is not conducive to the improvement of weaknesses, the promotion of preparedness, the enhancement of skills and the strengthening of management in similar future situations.

"... We did not record our experiences and everything remained only in our minds; after we're gone, there'll be no trace of our experiences ..." "... Whenever there's an earthquake, I believe these problems will be repeated ..." "... We constantly talk about problems at our meetings, but that's only talk ..." "... The experiences have not been transmitted even then, even if they move, they cannot solve the problem, they must work on the thoughts of managers...".

9- The challenges of communicating with the earthquake-affected areas and between teams

The participants noted communication problems, including the disconnection of communication systems in the early hours and the lack of communication equipment. According to the participants, it later became clear that communication problems had led to a lack of communication with the health centers and relief organizations. Other problems in this domain included the lack of public awareness, not knowing about the center of the earthquake during the early hours, and the lack of coordination between the organizations. There was a disorder in the provision of services as a result of these shortcomings.

"... Landlines and cellphones were completely cut off ..." "... We were not connected anywhere; our sites were mostly wireless. We did not have any other connections with the ambulance ..." "The satellite phone does not help much ..." "... We couldn't communicate with the hospitals and we didn't know which hospitals would take in the patients ..." "... They couldn't call us from the villages".

10- Recalling And Deploying Ems Responders

The interviewees discussed some positive points in their statements, such as the good recall and dispatch of EMS paramedics and the rapid receipt of donations from other provinces and neighboring cities. The high motivation and sense of responsibility in the relief forces to provide services and the spontaneous hastening of the pre-hospital personnel to help the earthquake victims were constantly discussed by the participants of this study.

... All our colleagues came, because everyone felt responsible ..." "... Several surgeons, anesthesiologists, physicians and nurses came ..." "... Our colleagues from Ardabil and Meshkin Shahr had reached Ahar even earlier than ourselves...

\section{Discussion}

Providing BLS in the early phase of disasters is a key component of disaster management. Following the twin earthquakes of East Azerbaijan in 2012, provincial EMS tried to provide BLS to the injured. This qualitative study was conducted to investigate the EMS response experience to the earthquake in Varzaghan, Haris and Ahar. According to the results of the interviews, there were many challenges in the EMS response to this incident, including the of preparedness and coordination, the challenges of dead bodies management, psychosocial support responders, deficiencies in supplies and ambulances, difficulty of access to rural areas, volunteer management, lack of documentation of experiences, communication challenges, calling and deploying of EMS responders.

In a recent study, Sorani et al. reviewed the challenges of pre-hospital emergency systems in disasters. They extracted six main categories of data, and apart from the challenges of medical care, the rest of the challenges were in line with those noted in the present study ${ }^{[11]}$. The six main categories of challenges in

Page 7/10 
Sorani's study were people challenges, infrastructure challenges, information management system challenges, staff challenges, managerial challenges and challenges in providing medical care.

In a study by Babaie et al. (2015) on the challenges of hospital response to disasters, the main challenges extracted included the lack of coordination, preparedness, equipment and supplies, as in line with the results of this study [12].

In a study by Khankeh et al., the poor planning in providing health services, poor division of labor, unclear duties, overlapping tasks, parallel functioning and poor connection between the managers and the service providers were major problems and obstacles in disaster management ${ }^{[13]}$.

Almost all the available health sectors, including pre-hospital EMS, hospitals, public health and support departments, were involved in the response to disasters; however, there was no coordination among them (either within the Ministry of Health (MOH) between the different departments or outside the MOH), as they kept their organizational boundaries rather than reinforcing each other, although the purpose of all of them was to provide health care to all those affected by the disaster.

In one study, Rubin (1998) stated that the initial response to disasters should include the transfer of the injured to healthcare facilities, the recall and management of healthcare personnel and the supply of medical equipment and other required facilities. Therefore, at this stage, the main activity is to properly coordinate the storage and distribution of facilities. The management of disaster response should immediately activate all the related organizations, issue necessary permits for resource consumption, specify the priorities and progress of work and assess and monitor the provision of services tailored to the objectives. The obtained information is collected, interpreted and explained and the service provider should also be introduced ${ }^{[14]}$.

The results of the study by Emami et al. (2005) entitled "Strategies in evaluation and management of Bam earthquake victims" revealed that a comprehensive plan is needed to ensure a comprehensive and consistent response to harmful events. It is effective on required services for injured people and screening has many benefits in assessing and managing the victims of accidents rapidly and effectively ${ }^{[15]}$.

People develop extensive health needs due to the wide disruptions that occur after disasters ${ }^{[13]}$. Responding to all these needs is almost beyond the control of the health authorities, and people should themselves act too, irrespective of the health system in place in their country ${ }^{[16]}$.

In the studied earthquakes, people came to the scene from the very first moments after the incident. Since the earthquake had affected a vast area -mostly rural areas - it was not possible to provide services to all of them in a limited time. The arrival of ordinary people helped quickly rescue the casualties from the rubble and transfer them to the health facilities. Many of these people had no training in emergency services and some of the volunteers may have themselves been harmed; in fact, some of them died in the second post-seismic period. In addition, their lack of awareness about the principles of service provision could have harmed other people as well. Previous studies have made note of similar problems ${ }^{[17]}$.

One of the challenges expressed by the interviewees was that the forces active on the scene did not use the lessons learnt from the past, which demonstrates the lack of documentation of the actions and the failure to transfer them to others for future use. The lessons learned in every disaster can become the basis of training and help increase the skills and readiness of the medical personnel and the general public in the face of similar situations. Therefore, by recording and documenting experiences, the level of preparedness, knowledge and skills can be raised in the community by organizing training courses for pre-hospital staff and ordinary people the transfer of experiences.

In the study by Khankeh et al., one of the solutions proposed for improving the services provided in critical situations was proper management, planning and preparation based on past experiences and the information derived from regional reviews, which facilitate planning and decision-making based on actual data [18].

In another study, Arabs et al. also emphasized the significant relationship between the knowledge and performance of executive directors and demonstrated the importance of the development and implementation of short-term training programs to increase the knowledge and awareness of hospital executives about coping with natural disasters and hazards, including earthquakes. In addition, general training and pre-event planning help provide an effective response to health services during a disaster ${ }^{[19]}$. Nonetheless, these lessons are usually not taken into account for a variety of reasons ${ }^{[20]}$.

The lack of psychosocial support for the staff was a neglected issue in participants' experience. The EMS personnel also have their own family, who may themselves be living in the earthquake-stricken areas and may have been harmed and need help. Meanwhile, almost no action was taken to help ensure the safety of the personnel's family, and the EMS personnel had to them ensure their family's health and safety. Furthermore, disasters create frustrating scenes that disturb the viewers' mental health. Ensuring that these issues are well taken care of requires actions that were not taken into consideration in this earthquake. Similar problems were noted in previous studies.

Communication is one of the main infrastructures and needs of any disaster response and is one of the essential tools for establishing coordination. The first consequence of disasters is the disconnection of communication or excessive burden on the means of communication due to the increased need for communication. Many disaster responding organizations have a multi-layered communication facility for themselves, and although the pre-hospital emergency department also has a separate communication system if its own, one of the biggest drawbacks discussed in the present study was the lack of communication facilities at the time of the earthquake. The failure to plan for a rapid assessment of the health needs, dispersion and inconsistency and prolonged data collection and analysis process mean that many decisions taken in response to emergency situations are based on previous experiences rather than actual data from the field, which was one of the problems discussed in the present study too.

\section{Conclusion}


According to the research findings, the EMS response for the twin earthquakes of Arasbaran in the presence and recall of paramedics and their sense of responsibility for providing services was a positive and successful experience in delivering emergency services; however, there were challenges and weaknesses in the management and coordination of the paramedics, most of which were due to the lack of preparedness. The transfer of experiences by planning and organizing courses can address the weaknesses of the current EMS system and will prevent the extent of disasters in the future.

\section{Abbreviations}

BLS

Basic Life Support

EMS

Emergency Medical Services

FGD

Focus Group Discussions

$\mathrm{MOH}$

Ministry of Health

\section{Declarations}

\section{Ethics approval and consent to participate}

This study reviewed and approved by Tabriz University of medical Sciences research ethical committee. Ethical code: IR.TBZMED.REC.1396.535

\section{Consent for publication}

Not applicable

\section{Availability of data and materials}

The datasets used and analyzed during the current study are available from the corresponding author on reasonable request

\section{Competing interests}

There is no conflict of interest

\section{Funding}

This study has been funded and supported by school of faculty medicine, Tabriz University of Medical Sciences. The funder has paid costs of study and coordinated FGD participants.

\section{Authors' contributions}

JB contributed in designing, analyzing data, and finalizing the paper. MP contributed in data collection through semi structured interviewees, and transcription of interviews, LR analyzed and interviewees. JB has critically revised the manuscript for important intellectual content. All authors read and approved the final version of the paper.

\section{Acknowledgements}

This study was part of an Emergency Medicine thesis/dissertation supported by Tabriz University of Medical Sciences.

\section{References}

1. 10.1371/currents.dis.c72864d9c7ee99ff8fbe9ea707fe4465

-Babaie J, Ardalan A, Vatandoost H, Goya MM, Akbarisari A. Performance assessment of communicable disease surveillance in disasters: A systematic review. PLOS Currents Disasters. 2015 Feb 24. Edition 1. doi: 10.1371/currents.dis.c72864d9c7ee99ff8fbe9ea707fe4465.

2. -Guha-Sapir D, Vos F, Below R. Ponserre S. Annual Disaster Statistical R. 2014: The numbers and trends. WHO collaborating Centre for Research on the Epidemiology of Disasters - CRED available on http://www.cred.be/sites/default/files/ADSR_2014.pdf.

3. -Doocy S, Daniels A, Packer C, Dick A, Kirsch TD. The Human Impact of Earthquakes: a Historical Review of Events 1980-2009 and Systematic Literature Review. PLOS Currents Disasters. 2013 Apr 16 doi:10.1371/currents.dis.67bd14fe457f1db0b5433a8ee20fb833.

4. -CRED. Natural disasters in 2017: lower mortality, higher cost. Dec 13, 2017. Accessed: Aug 22, 2018. Available: https://cred.be/sites/default/files/credcrunch50.pdf.

5. -Khankeh HR, Khorasani-Zavareh D, Johanson E, Mohammadi R, Ahmadi F, Mohammadi R. Disaster health-related challenges and requirements: A grounded theory study in Iran. Prehosp Disaster Med. 2011;26(3):151-8.

6. -Ardalan A, Kandi M, Osooli M, et al. Profile of natural hazards in I.R.Iran, Disaster and emergency health academy, Iran's national institute of health research and SPH of Tehran university of medical sciences, 2012. 
7. -Djalali A, Khankeh H, Ohlen G, Castren M, Kurland L. Facilitators and obstacles in pre-hospital medical response to earthquakes: A qualitative study. Scandinavian journal of trauma, resuscitation and emergency medicine. 2011; 19-30.

8. -Catlett CL, Jenkins JL, Millin MG. Role of emergency medical services in disaster response: resource document for the National Association of EMS Physicians position statement. Prehosp Emerg Care. 2011 Jul-Sep;15(3):420-5. doi:10.3109/10903127.2011.561401. Epub 2011 Apr 11.

9. -Djalali AR, Casteren M, Hosseini jenab V, Khatib M, Ohlen G, Kurland L. Hospital incident command system (HICS) performance in Iran: Decision making during disasters. Scandinavian journal of trauma. 2012.

10. 10.1371 /currents.dis.308f6140d54f78fd1680e2b9e6460ae3 -Babaie J, Moslehi S, Ardalan A. Rapid Health Needs Assessment Experience in 11 August 2012 East Azerbaijan Earthquakes: A Qualitative Study. PLOS Currents Disasters. 2014 Jul 7. Edition 1. doi: 10.1371/currents.dis.308f6140d54f78fd1680e2b9e6460ae3.

11. -Sorani M, Tourani S, Khankeh HR, Panahi S. Prehospital emergency medical services challenges in disasters: a qualitative study. Emergency. 2018;6(1):e26.

12. -Pouraghaei M, Jannati A, Moharamzadeh P, Ghaffarzad A, Far MH, Babaie J. Challenges of Hospital Response to the Twin Earthquakes of August 21, 2012, in East Azerbaijan, Iran. Disaster Med Public Health Prep. 2017 Aug; 11(4):422-430. doi: 10.1017/dmp.2016.153. Epub 2017 Jan 9.

13. -Khankeh HR, Mohammadi R, Ahmadi F. Barriers and Facilitators of Health Care Services at the Time of Natural Disasters. jrehab. 2005;6(1):23-30.

14. -Rubin JN. Recurring Pitfalls in Hospital Preparedness and Response. Hospital Preparation for Bioterror: A Medical and Biomedical Systems Approach. Amesterdam: Academic Press; 2006. p. 1.

15. -Emami MJ, Tavakoli AR, Alemzadeh H, Abdinejad F, Shahcheraghi G, Erfani MA, Mozafarian K, Solooki S, Rezazadeh S, Ensafdaran A, Nouraie H, Jaberi FM, Sharifian M. Strategies in evaluation and management of Bam earthquake victims. Prehosp Disaster Med. 2005 Sep-0ct;20(5):327-30.

16. -Patterson O, Weil F, Patel K. The Role of Community in Disaster Response: Conceptual Models. Popul Res Policy Rev. 2010;29:127-41.

17. -Méheux K, Dominey-Howes D, Lloyd K. Operational challenges to community participation in post-disaster damage assessments: observations from Fiji. Disasters. 2010 Oct;34(4):1102-22. doi:10.1111/j.1467-7717.2010.01185.x.

18. -Khankeh HR. National hospital disaster preparedness plan. University of welfare and rehabilitation. Tehran, 2011.

19. -Arab M, Zeraati H, Akbari Haghighi F, Ravangard R. A study on the executive managers' knowledge and performance, and their hospitals preparedness against earthquake events and their relationships at public hospitals (affiliated by Tehran University of Medical Sciences (TUMS) 2005-2006). Journal of health administration. 2009;11(34):7-14.

20. -Donahue A, Tuohy R. "Lessons We Don't Learn: A Study of the Lessons of Disasters, Why We Repeat Them, and How We Can Learn Them." Homeland Security Affairs 2, Article 4 (July 2006). https://www.hsaj.org/articles/167. 